\title{
Tracing radioactive cesium in stem wood of three Japanese conifer species 3 years after the Fukushima Dai-ichi Nuclear Power Plant accident
}

\author{
Shinta Ohashi ${ }^{1,2^{*}}$, Katsushi Kuroda ${ }^{1}$, Takeshi Fujiwara ${ }^{1,3}$ and Tsutomu Takano ${ }^{2}$
}

\begin{abstract}
To understand the dynamics of accident-derived radioactive cesium $\left({ }^{137} \mathrm{Cs}\right)$ in stem wood that had a substantial amount of heartwood at the time of the Fukushima Dai-ichi Nuclear Power Plant accident, the radial and vertical distributions of ${ }^{137} \mathrm{Cs}$ activity concentration in stem wood of Japanese cedar (Cryptomeria japonica), cypress (Chamaecyparis obtusa), and larch (Larix kaempferi) were investigated. In addition, the natural distribution of stable cesium $\left({ }^{133} \mathrm{Cs}\right.$ ), rubidium $\left({ }^{85} \mathrm{Rb}\right)$, and potassium $\left({ }^{39} \mathrm{~K}\right)$ concentrations was analyzed to determine the characteristics of ${ }^{137} \mathrm{Cs}$ distribution. Wood disks were collected from the tree stems of six cedars, three cypresses, and two larches at multiple heights in 2014, and the concentrations were measured every $2 \mathrm{~cm}$ in the radial direction. ${ }^{137} \mathrm{Cs}$ distribution in stem wood differed among tree species, sampling site, and vertical position of the stem within a tree. Statistical analyses suggested that the radial distribution of ${ }^{137} \mathrm{CS}$ within the heartwood can be explained by the heartwood moisture content and the distance from the treetop, regardless of species, while the distribution between sapwood and heartwood was dependent on the heartwood cross-sectional area and was additionally different between larch and other species. Similarly, the heartwood/sapwood concentration ratios of stable alkali metals differed between larch and the other species. In the larch, the ratio was ca. 0.5 for all elements, but the ratio was over 1.0 and differed among elements in the other species. Consequently, the species-specific difference in the distribution of ${ }^{137} \mathrm{Cs}$ between sapwood and heartwood was considered to be due to different activity levels of radial transport toward the heartwood. The radial variation pattern of the ${ }^{137} \mathrm{Cs} /{ }^{133} \mathrm{Cs}$ concentration ratio showed that less ${ }^{137} \mathrm{Cs}$ was transferred to the inner heartwood compared with the ${ }^{133} \mathrm{Cs}$ distribution pattern in many trees; however, there was also a tree in which ${ }^{137} \mathrm{Cs}$ was excessively transferred to the inner heartwood compared with the ${ }^{133} \mathrm{Cs}$ distribution pattern. Such patterns may result from a combination of significant foliar uptake of ${ }^{137} \mathrm{Cs}$ and poor root uptake after the accident, in addition to the high moisture content of the heartwood.
\end{abstract}

Keywords: Alkali metals, Radial distribution, Vertical distribution, Sapwood, Heartwood, Cedar, Cypress, Larch

*Correspondence: shinta.res@gmail.com

1 Department of Wood Properties and Processing, Forestry and Forest Products Research Institute, 1 Matsunosato, Tsukuba, Ibaraki 305-8687, Japan

Full list of author information is available at the end of the article

\begin{abstract}
Introduction
Radioactive cesium $\left({ }^{137} \mathrm{Cs}\right)$ dispersed into the atmosphere by a nuclear weapon test or power plant accident is transferred into trees mainly by two pathways, namely, foliar uptake and root uptake $[1,2]$. A major part of the foliar uptake of ${ }^{137} \mathrm{Cs}$ is assumed to occur shortly after a ${ }^{137} \mathrm{Cs}$ deposition event, when the fraction of dissolved ${ }^{137} \mathrm{Cs}$ in throughfall and precipitation is high [3], and can be the
\end{abstract}


major source of initial ${ }^{137} \mathrm{Cs}$ input to trees that have needles or leaves at the time of the deposition event [4]. Subsequently, as the amount of ${ }^{137} \mathrm{Cs}$ in throughfall decreases exponentially with time $[3,5]$, root uptake becomes the dominant source of ${ }^{137} \mathrm{Cs}$ input to trees over the long term [1]. Recently, bark uptake was experimentally demonstrated to be another possible pathway [6,7]; however, its contribution in the actual situation remains unclear, and its main contribution seems to occur shortly after the deposition event for the same reason as foliar uptake.

Regardless of the pathways, a portion of the ${ }^{137} \mathrm{Cs}$ absorbed into trees can be distributed in stem wood. As with other alkali metals (e.g., $\mathrm{K}$ and $\mathrm{Rb}$ ), Cs absorbed from the surface of foliage can be translocated to tree stems via the phloem (inner bark) [8] and partly transported to the sapwood via the rays [9]. Cs absorbed from the roots moves upward with sap flow in the sapwood. Within the sapwood, Cs can be redistributed widely by transport via the axial and ray parenchyma cells and by diffusion in free water [10-12]. Although the transfer processes of alkali metals from sapwood to heartwood are not fully understood, many studies have observed accident-derived ${ }^{137} \mathrm{Cs}$ in the heartwood [e.g., 13, 14], and an experimental study suggested the possibility of active transport via ray parenchyma cells and diffusion in the cell walls of the intermediate wood (the transition zone between sapwood and heartwood) [11, 12]. Finally, within the heartwood, because there are no living cells, alkali metals transfer by diffusion in free water, which is generally less available in the heartwood than in the sapwood.

Due to the complex and uncertain transfer processes described above and the heterogeneous distribution of water, especially in the heartwood $[15,16],{ }^{137} \mathrm{Cs}$ is expected to show non-uniform distribution in stem wood. Actually, the radial and/or vertical distributions of ${ }^{137} \mathrm{Cs}$ activity concentration in stem wood affected by the Fukushima Dai-ichi Nuclear Power Plant (FDNPP) accident have been found to be heterogeneous and species-dependent $[4,14,17-20]$. In addition, a monitoring survey has suggested the possibility of temporal change in ${ }^{137} \mathrm{Cs}$ distribution (progression of ${ }^{137} \mathrm{Cs}$ transfer to the inner parts of the heartwood) [18]. Thus, understanding the current situation and temporal change of ${ }^{137} \mathrm{Cs}$ distribution in stem wood is necessary for predicting ${ }^{137} \mathrm{Cs}$ contamination of wood. It is also important for estimating the ${ }^{137} \mathrm{Cs}$ contamination of an entire stem wood from a small sample (e.g., a sapwood core at breast height).

When the ${ }^{137} \mathrm{Cs}$ dynamics in a forest ecosystem reach the equilibrium state, the distribution pattern of ${ }^{137} \mathrm{Cs}$ in a tree is assumed to be similar to that of the naturally distributed stable isotope of cesium $\left({ }^{133} \mathrm{Cs}\right)$ [21]. However, it is uncertain whether the distribution patterns of
${ }^{137} \mathrm{Cs}$ and ${ }^{133} \mathrm{Cs}$ really match well in the equilibrium state, because their transfer processes are different in mature trees that had a substantial amount of heartwood at the time of the deposition event. Accident-derived ${ }^{137} \mathrm{Cs}$ is transferred into trees by both foliar and root uptake and into the heartwood after its formation, whereas ${ }^{133} \mathrm{Cs}$ is transferred into trees by root uptake and is incorporated into the heartwood with its formation. Although the influence of foliar uptake on the distribution of ${ }^{137} \mathrm{Cs}$ in stem wood is still unknown, similarity between ${ }^{137} \mathrm{Cs}$ and ${ }^{133} \mathrm{Cs}$ distribution patterns in stem wood has been found in a Scots pine (Pinus sylvestris) collected 12 years after the Chernobyl Nuclear Power Plant (CNPP) accident [21]. However, because the reported pine was about 20 years old at the time of the accident and probably had a small amount of heartwood, it is unclear whether this similarity can be found in older and larger trees with a substantial amount of heartwood. This is a big concern, especially in the case of the FDNPP accident, because Japanese cedar (Cryptomeria japonica) and cypress (Chamaecyparis obtusa), which are key species for forestry in the contaminated area, have larger heartwood fractions than Scots pine and also because they have the species-specific characteristic that the Cs concentration is higher in the heartwood than in the sapwood [22, 23].

Our long-term goal is to clarify temporal changes in the distribution of accident-derived ${ }^{137} \mathrm{Cs}$ in stem wood from the non-equilibrium state to the equilibrium state, especially in mature trees that had a substantial amount of heartwood at the time of the accident. As the first step, this study aims to understand the characteristics of the radial and vertical distributions of ${ }^{137} \mathrm{Cs}$ activity concentration in stem wood 3 years after the FDNPP accident, assuming that the distributions were still in the non-equilibrium state. We targeted three major conifer species in the contaminated area: two evergreen conifer species, namely, Japanese cedar (Cryptomeria japonica [L.f.] D.Don) and cypress (Chamaecyparis obtusa [Siebold et Zucc.] Endl.), and one deciduous conifer species, namely, Japanese larch (Larix kaempferi [Lamb.] Carrière). The characteristics of ${ }^{137} \mathrm{Cs}$ distribution in stem wood were evaluated by statistical analyses and by comparison with stable alkali metals $\left({ }^{133} \mathrm{Cs}\right.$, ${ }^{85} \mathrm{Rb}$, and $\left.{ }^{39} \mathrm{~K}\right)$.

\section{Materials and methods}

\section{Sample collection and preparation}

Samples were collected from three sites in August and September 2014. Sites 1 and 2 were located in Kawauchi Village of Fukushima Prefecture, and site 5 was located in Ishioka City of Ibaraki Prefecture (Fig. 1; site identifications correspond to those in Ohashi et al. [24]). As of December 28, 2012, the deposition densities of ${ }^{137} \mathrm{Cs}$ after the FDNPP accident were 390, 140, and $11 \mathrm{kBq} \mathrm{m}^{-2}$ at 


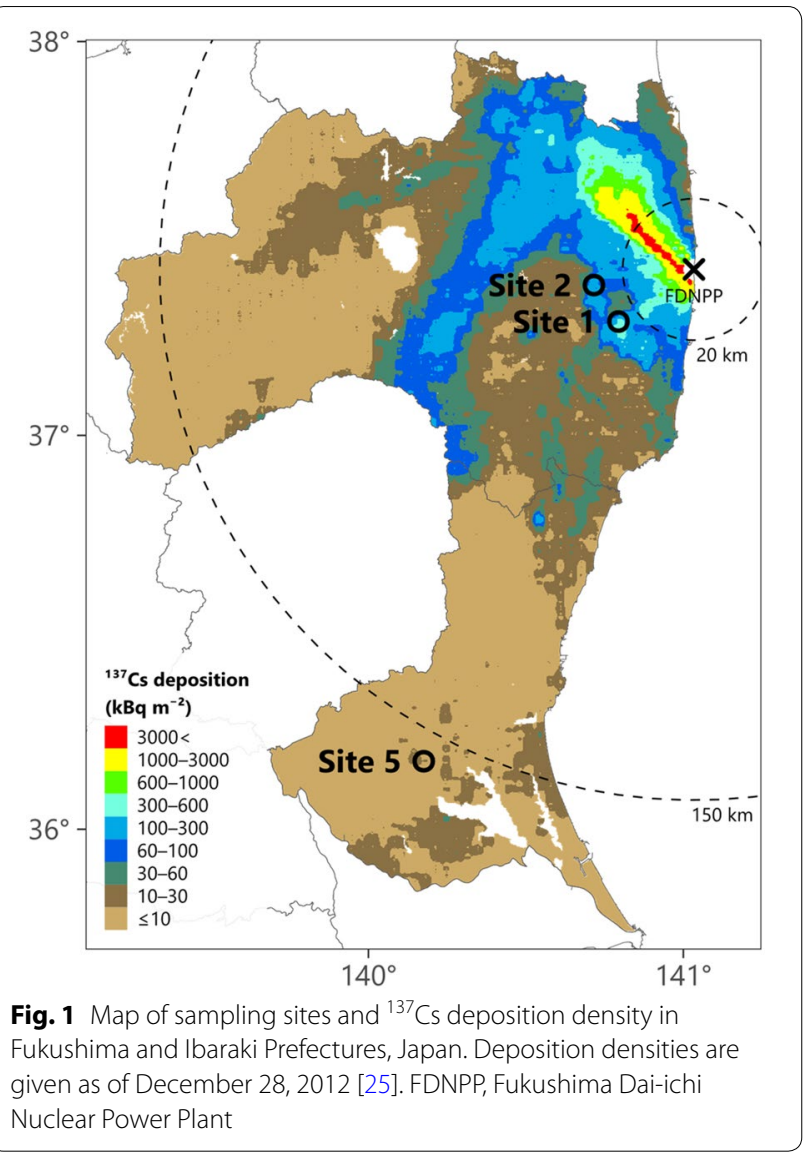

site 1,2 , and 5 , respectively [25]. Japanese cedar samples were collected from sites 1 and 2, cypress samples from site 5 , and larch samples from site 2 . Although collecting wood samples from the same individual over a long period is ideal, we collected wood disks from multiple individuals in this study because it was difficult to obtain an adequate amount of sample for ${ }^{137} \mathrm{Cs}$ measurements by core sampling and to get samples from the upper parts of the stems without felling the trees. We cut down three individuals from different classes of diameter at breast height (DBH) at each site for the cedar and cypress (sizes were identified as large (L), medium (M), and small (S) according to relative size of the DBH in each site) and two individuals for the larch (sizes were identified $L$ and $M$ ). Before collecting the wood disks, the bark was removed with a saw and scraper to prevent highly contaminated bark from mixing into the wood. Then, several wood disks about $5 \mathrm{~cm}$ thick were cut from multiple heights of the stems with a chainsaw. The sampling heights were 1,5 , and $10 \mathrm{~m}$ above the ground for size $\mathrm{L}$ and $\mathrm{M}$ trees (also 15 and $20 \mathrm{~m}$ for tall trees in site 2) and $1 \mathrm{~m}$ for size $\mathrm{S}$ trees. In addition, disks were collected from 2.5 and $4.5 \mathrm{~m}$ above the ground to evaluate the heartwood moisture content of each tree. Details of the sampled trees are shown in Table 1.

Each wood disk was divided every $2 \mathrm{~cm}$ in a radial direction with the sapwood-heartwood boundary as a starting point. The sapwood-heartwood boundary, which was mostly narrow and indistinct, was regarded as the middle of the intermediate wood for the cypress and larch samples. On the other hand, the intermediate wood was treated as an independent sample for the cedar samples, because it was wide (about $1 \mathrm{~cm}$ in the radial direction) and distinct in all disks. The edge of a disk sector (i.e., the outermost sapwood or innermost heartwood) was included in the adjacent sample when its radial length was less than $1 \mathrm{~cm}$, and it was obtained as an independent sample when its radial length was $1 \mathrm{~cm}$ or longer; however, the innermost heartwood for which the

Table 1 Description of the sampled trees

\begin{tabular}{|c|c|c|c|c|c|c|c|}
\hline Species & Site ID & Age (year) & Size ID ${ }^{a}$ & $\mathrm{DBH}(\mathrm{cm})$ & Height (m) & $\mathrm{LBH}(\mathrm{m})$ & HWMC (\%) \\
\hline Cedar & 1 & 46 & $L$ & 32.9 & 19.1 & 5.0 & 97 \\
\hline \multirow[t]{5}{*}{ (Cryptomeria japonica) } & & & M & 28.6 & 18.1 & 9.0 & 73 \\
\hline & & & $S$ & 20.8 & 16.1 & 5.5 & 65 \\
\hline & 2 & 60 & $L$ & 48.8 & 25.9 & 10.5 & 53 \\
\hline & & & $M$ & 39.2 & 26.1 & 10.2 & 69 \\
\hline & & & $\mathrm{S}$ & 30.4 & 24.8 & 17.2 & 61 \\
\hline Cypress & 5 & 46 & $L$ & 29.4 & 18.6 & 9.0 & 35 \\
\hline \multirow[t]{2}{*}{ (Chamaecyparis obtusa) } & & & $M$ & 22.1 & 17.7 & 12.0 & 46 \\
\hline & & & $\mathrm{S}$ & 17.6 & 16.7 & 10.5 & 41 \\
\hline Larch & 2 & $>50$ & $L$ & 34.6 & 25.3 & 15.9 & 41 \\
\hline (Larix kaempferi) & & & $M$ & 31.4 & 25.9 & 15.1 & 38 \\
\hline
\end{tabular}

$D B H$ diameter at breast height, $L B H$ lowest branch height, $H W M C$ heartwood moisture content

a Relative size of DBH at each sampling site

b Mean moisture content of wood disks collected at 2.5 and $4.5 \mathrm{~m}$ height 
radial length was less than $1 \mathrm{~cm}$ was not analyzed because its amount was not enough for ${ }^{137} \mathrm{Cs}$ measurement.

\section{Determination of radioactive cesium $\left({ }^{137} \mathrm{Cs}\right)$ activity concentration}

The samples were chipped using a cutting mill with a 6-mm sieve (UPC-140, HORAI, Higashiosaka, Japan) and packed into polystyrene containers (type U-8 [100 mL] or $\mathrm{V}-1[550 \mathrm{~mL}])$ for measurement of radioactivity. Because of the low heat resistance of the container, the sample mass was measured after oven-drying at $75{ }^{\circ} \mathrm{C}$ for $48 \mathrm{~h}$ and then converted to a dry mass at $105^{\circ} \mathrm{C}$ by multiplying by the conversion factor (0.99) [24]. The radioactivity of ${ }^{137} \mathrm{Cs}$ in the samples was determined using gamma-ray spectrometry with a high-purity Ge detector (GEM20-70, GEM40P4-76, GEM-FX7025P4-ST, or GWL-120-15-LBAWT, ORTEC, TN, USA). Measurement accuracy was checked using soil sample 01 of the IAEA-CU-2006-03 worldwide proficiency test for the determination of gamma-emitting radionuclides (IAEA/AL/171). Finally, the activity concentration $\left(\mathrm{Bq} \mathrm{kg}{ }^{-1}\right)$ of ${ }^{137} \mathrm{Cs}$ was calculated on a dry mass $\left(105^{\circ} \mathrm{C}\right)$ basis and decay-corrected to September 1, 2014.

\section{Determination of concentrations of stable alkali metals} $\left({ }^{133} \mathrm{Cs},{ }^{85} \mathrm{Rb}\right.$, and $\left.{ }^{39} \mathrm{~K}\right)$

The concentrations of stable cesium $\left({ }^{133} \mathrm{Cs}\right)$, rubidium $\left({ }^{85} \mathrm{Rb}\right)$, and potassium $\left({ }^{39} \mathrm{~K}\right)$ in wood samples collected from 1 and $10 \mathrm{~m}$ above the ground (and also from $20 \mathrm{~m}$ above the ground for the site 2 cedar) were measured for size $\mathrm{L}$ individuals at each site. The chipped samples were further homogenized using a cutting mill with a $2-\mathrm{mm}$ sieve (P-15, FRITSCH, Idar-Oberstein, Germany). Then, about $0.1 \mathrm{~g}$ of each sample was digested in a polypropylene tube with $\mathrm{HNO}_{3}(68 \%, 2 \mathrm{~mL})$ heated to $110{ }^{\circ} \mathrm{C}$ with a block digestion system (DigiPREP Jr, SCP SCIENCE, Quebec, Canada), with the addition of supplementary $\mathrm{H}_{2} \mathrm{O}_{2}$ (35\%, 0.5-1 mL). The digested sample was diluted by adding $\mathrm{HNO}_{3}(2 \%)$ up to $10 \mathrm{~mL}$ and filtered through a $0.45-\mu \mathrm{m}$ PTFE membrane. It was additionally diluted 101 times for the measurement of ${ }^{39} \mathrm{~K}$ concentration. The concentrations of stable alkali metals were determined using an inductively coupled plasma mass spectrometer (Agilent 7700x, Agilent Technologies, Santa Clara, USA), a calibration standard (XSTC-331, SPEX CertiPrep, NJ, USA), and internal standards (Sc: ICP-MS-50N-0.01X-1, Y: ICP-MS-69N-0.01X-1, Ce: ICP-MS-11N-0.01X-1, AccuStandard, CT, USA). Measurement accuracy was checked using a standard reference material (1575a Pine Needles, NIST, MD, USA).

\section{Statistical analysis of ${ }^{137} \mathrm{Cs}$ distribution}

To understand the characteristics of ${ }^{137} \mathrm{Cs}$ distribution in stem wood, statistical analyses were performed using linear mixed models (LMMs) with a random effect of individual trees. Because the ${ }^{137} \mathrm{Cs}$ transfer mechanism from sapwood to heartwood and that within the heartwood are assumed to be different, we used two different models: sapwood to heartwood (SW-to-HW) and within-HW models.

The response variables were the concentration ratio of ${ }^{137} \mathrm{Cs}$ in the heartwood to sapwood (HW/SW CR of ${ }^{137} \mathrm{Cs}$ ) in the SW-to-HW model and the concentration ratio of ${ }^{137} \mathrm{Cs}$ in the innermost heartwood to the outermost heartwood $\left(\mathrm{HW}_{\text {inner }} / \mathrm{HW}_{\text {outer }} \mathrm{CR}\right.$ of $\left.{ }^{137} \mathrm{Cs}\right)$ in the within-HW model. If the sapwood or heartwood of the wood disk was divided into subsamples, we used the mass-weighted mean concentration of ${ }^{137} \mathrm{Cs}$ in the sapwood or heartwood in the SW-to-HW model.

Based on the following hypotheses or reported observations, we designated eight variables as fixed effects in both the SW-to-HW and the within-HW models (Table 2). (1) Heartwood cross-sectional area (HWA) of wood disk: in a wood disk with larger HWA, the ${ }^{137} \mathrm{Cs}$ concentration in the heartwood is more diluted, and it takes a longer time for ${ }^{137} \mathrm{Cs}$ to transfer to the inner

Table 2 List of the variables (fixed effects) used in the SW-to-HW and the within-HW models (before model selection)

\begin{tabular}{lll}
\hline Variable & Type & Explanation \\
\hline HWA & Continuous & Heartwood cross-sectional area of wood disk \\
HWCL-per-HWA & Continuous & Heartwood circumferential length per HWA of wood disk \\
CROWN & Categorical & Whether a wood disk is located in the tree crown or not \\
D-from-T & Continuous & Distance from the treetop of wood disk \\
HWMC & Continuous & Heartwood moisture content of the tree \\
LARCH & Categorical & Unmeasured species effect of larch (reference category is cedar) \\
SITE2 & Categorical & Unmeasured site effect of site 2 (reference category is site 1) \\
CYPRESS-SITE5 & Categorical & Unmeasured species and site effects of cypress and site 5 (refer- \\
& & ence category is site-1 cedar)
\end{tabular}


parts of the heartwood. (2) Heartwood circumferential length per HWA (HWCL-per-HWA) of wood disk: when HWCL-per-HWA is longer (or heartwood diameter is smaller), ${ }^{137} \mathrm{Cs}$ transfers from sapwood to heartwood more efficiently. (3) Whether a wood disk is located in the tree crown or not (or is located at a higher position than the lowest living branch or not) (CROWN): the ${ }^{137} \mathrm{Cs}$ concentration in the inner parts of a wood disk located within the tree crown is likely to be higher than that in the inner parts of a wood disk located below the tree crown [26]. (4) Distance from the treetop (D-from$\mathrm{T}$ ) of wood disk: Ogawa et al. [18] reported that the ${ }^{137} \mathrm{Cs}$ activity concentration in the heartwood tended to be higher in positions closer to the treetop and suggested that $\mathrm{D}$-from- $\mathrm{T}$ is a better explanatory variable than distance from the ground to explain the vertical distribution of ${ }^{137} \mathrm{Cs}$ in the heartwood. Although D-from-T is somewhat correlated (not significantly) with HWA, HWCLper-HWA, and CROWN, we designated this variable to consider unexplained effects related to vertical position in the stem. (5) Heartwood moisture content (HWMC) of the tree: ${ }^{137} \mathrm{Cs}$ transfers more easily to inner parts of the heartwood when HWMC is higher. Iizuka et al. [20] reported that the radial distribution of ${ }^{137} \mathrm{Cs}$ activity concentration in Japanese cedars with high HWMC was relatively uniform throughout the heartwood compared with that in cedars with low HWMC. In this study, HWMC of the tree (mean of HWMC values of wood disks sampled from 2.5 and $4.5 \mathrm{~m}$ above the ground) was used because HWMC data for each disk were not available. (6-8) Tree species and sampling site (LARCH, SITE2, CYPRESSSITE5): to detect other effects that are not explained by the above five variables and arise from differences between tree species and sampling sites, the effects of larch (LARCH) and site 2 (SITE2) were included in the models, setting "cedar" as the reference category of species and "site 1" as the reference category of site. The effects of cypress and site 5 were combined into one variable (CYPRESS-SITE5), because the cypress samples were collected from the single site (site 5) that was different from the sampling sites of the other two species, and we cannot distinguish the effects of cypress and site 5 .

All statistical analyses were performed using $\mathrm{R}$ version 3.6.1 [27]. The response variables were transformed to their common logarithms. Data from size $S$ trees were not used in the analyses, because these data are only from disks sampled at $1 \mathrm{~m}$ above the ground. In addition, the wood disk from the size L larch collected at $20 \mathrm{~m}$ above the ground was eliminated from the within-HW model analysis because it was not divided into subsamples. The four fixed effects, CROWN, LARCH, SITE2, and CYPRESS-SITE5, are categorical variables, and the other fixed effects are continuous variables that were centered by subtracting their means and scaled by dividing them by their standard deviations. Multicollinearity in the model including all the fixed effects was checked using the variance inflation factor (VIF) [28], and none of the fixed effects were eliminated here, judging by the criterion that VIF should not exceed 10. Tentative models derived from all combinations of the fixed effects were fitted to the data using the lmer function in the lme4 package [29], and Akaike's information criterion (AIC) value was calculated for each model. Finally, we selected the model with the lowest AIC value as the most reasonable model (selected independently for the SW-to-HW and within-HW models).

\section{Results}

Radioactive cesium $\left({ }^{137} \mathrm{Cs}\right)$

The radial distribution of ${ }^{137} \mathrm{Cs}$ activity concentration in stem wood varied not only among species, but also among trees of the same species collected from different sites and among vertical positions of the stem within tree (Fig. 2). Nevertheless, the radial distribution at the same sampling height showed high reproducibility among trees from the same site. The vertical distribution of ${ }^{137} \mathrm{Cs}$ activity concentration in the sapwood was almost uniform in all trees, whereas that in the heartwood was nonuniform and was higher in the upper parts of the stems in most trees.

Comparison of the ${ }^{137} \mathrm{Cs}$ activity concentration in the sapwood and the heartwood showed that most wood disks of cedar and cypress had higher concentrations in the heartwood than in the sapwood (Fig. 2a-i). However, disks from site- 2 cedars collected at or below $10 \mathrm{~m}$ above the ground and disks from site- 5 cypresses collected at or below $5 \mathrm{~m}$ above the ground had lower concentrations in the heartwood than in the sapwood (Fig. 2d-i). In contrast to these two species, larch had lower concentrations in the heartwood than in the sapwood at all sampling heights (Fig. 2j, k). The activity concentration in the intermediate wood of the cedar was within the range of that in the innermost sapwood and that in the outermost heartwood in most disks (Fig. 2a-f).

The radial distribution of ${ }^{137} \mathrm{Cs}$ activity concentration within the heartwood showed an increasing pattern toward the pith or was almost uniform throughout the heartwood in the upper parts of the stems (at or above $15 \mathrm{~m}$ above the ground in the site- 2 cedars, at $10 \mathrm{~m}$ in the site- 5 cypresses, and at $20 \mathrm{~m}$ in the site- 2 larch) and showed a decreasing pattern toward the pith in the lower parts of the stems (Fig. 2). However, in the site-1 cedars, the distribution within the heartwood was almost uniform, even in the lowest part of the stems ( $1 \mathrm{~m}$ above the ground). 


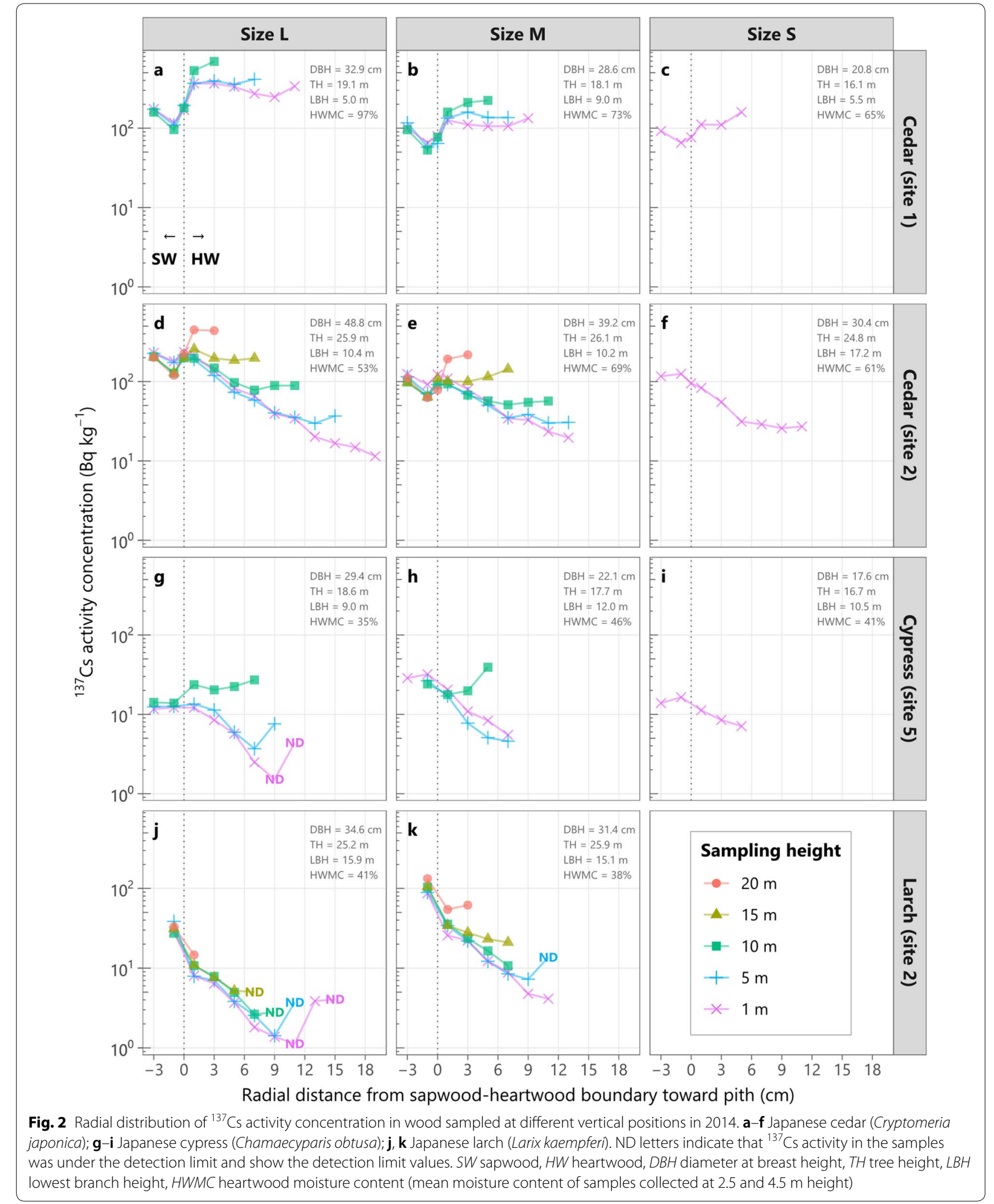


Table 3 Regression coefficients of the SW-to-HW model (after model selection)

\begin{tabular}{lcll}
\hline Variable & Coefficient & SE & $\mathbf{9 5 \% ~ C l}$ \\
\hline (Intercept) & 0.07 & 0.08 & -0.09 to 0.23 \\
HWA & -0.14 & 0.02 & -0.19 to -0.09 \\
LARCH & -0.66 & 0.16 & -0.97 to -0.35 \\
\hline
\end{tabular}

The response variable is $\log _{10}$ (concentration ratio of ${ }^{137} \mathrm{Cs}$ in heartwood to sapwood)

SW sapwood, HW heartwood, SE standard error, Cl confidence interval, HWA heartwood cross-sectional area

Table 4 Regression coefficients of the within-HW model (after model selection)

\begin{tabular}{lccc}
\hline Variable & Coefficient & SE & $\mathbf{9 5 \% ~ C l}$ \\
\hline (Intercept) & -0.30 & 0.04 & -0.37 to -0.23 \\
D-from-T & -0.28 & 0.04 & -0.35 to -0.21 \\
HWMC & 0.13 & 0.04 & 0.06 to 0.21
\end{tabular}

The response variable is $\log _{10}$ (concentration ratio of ${ }^{137} \mathrm{Cs}$ in innermost heartwood to outermost heartwood)

$H W$ heartwood, SE standard error, $C l$ confidence interval, $D$-from- $T$ distance from the treetop, HWMC heartwood moisture content

As a result of the statistical analysis of the SW-to-HW model, the LMM model including HWA (heartwood cross-sectional area) and $\mathrm{LARCH}$ as fixed effects was selected to explain the HW/SW CR of ${ }^{137} \mathrm{Cs}$. The other effects (HWCL-per-HWA, CROWN, D-from-T, HWMC, SITE2, and CYPRESS-SITE5) were not included in the selected model. The regression coefficients of HWA and LARCH were both negative, meaning that the HW/SW CR of ${ }^{137} \mathrm{Cs}$ was lower in disks with larger HWA and was lower in the larch than in cedar and site- 5 cypress (Table 3). The variance of the random effect (trees) was 0.04 . The coefficient of determination $\left(R^{2}\right)$ of the simple regression analysis between the estimated and observed values was 0.91 .

For the within-HW model, the LMM model including D-from-T (distance from the treetop) and HWMC (heartwood moisture content) as fixed effects was selected to explain the $\mathrm{HW}_{\text {inner }} / \mathrm{HW}$ outer $\mathrm{CR}$ of ${ }^{137} \mathrm{Cs}$. The regression coefficient of $\mathrm{D}$-from- $\mathrm{T}$ was negative and that of HWMC was positive, meaning that the $\mathrm{HW}_{\text {inner }} /$ $\mathrm{HW}_{\text {outer }} \mathrm{CR}$ of ${ }^{137} \mathrm{Cs}$ was lower in the disk farther from the treetop and higher in trees with higher HWMC (Table 4). The variance of the random effect (trees) was estimated to be 0 , suggesting that there was no consistent random effect among trees. $R^{2}$ of the simple regression analysis between the estimated and observed values was 0.72 .
Stable alkali metals $\left({ }^{133} \mathrm{Cs},{ }^{85} \mathrm{Rb}\right.$, and $\left.{ }^{39} \mathrm{~K}\right)$

The radial and vertical distribution patterns of concentrations of the stable alkali metals in the stem wood were similar among the elements in all analyzed trees (Fig. 3). However, the HW/SW CRs of ${ }^{133} \mathrm{Cs},{ }^{85} \mathrm{Rb}$, and ${ }^{39} \mathrm{~K}$ (mean \pm standard deviation) were $2.5 \pm 0.8,5.3 \pm 1.1$, and $6.6 \pm 1.2$ in the cedar; $1.4 \pm 0.7,2.1 \pm 1.0$, and $2.5 \pm 1.1$ in the cypress; and $0.5 \pm 0.1,0.4 \pm 0.0$, and $0.5 \pm 0.0$ in the larch, respectively; that is, the $\mathrm{HW} / \mathrm{SW}$ CR was high in the order of $\mathrm{K}, \mathrm{Rb}$, and $\mathrm{Cs}$ in the cedar and cypress, and was similar among $\mathrm{K}, \mathrm{Rb}$, and $\mathrm{Cs}$ in the larch.

\section{Comparison between radioactive and stable cesium}

The ratio of ${ }^{137} \mathrm{Cs}$ activity concentration to ${ }^{133} \mathrm{Cs}$ concentration $\left({ }^{137} \mathrm{Cs} /{ }^{133} \mathrm{Cs}\right.$ ratio) was calculated to compare the distribution patterns of ${ }^{137} \mathrm{Cs}$ and ${ }^{133} \mathrm{Cs}$, and its radial distribution in each disk is shown in Fig. 4. The ${ }^{137} \mathrm{Cs} /{ }^{133} \mathrm{Cs}$ ratio in the heartwood showed decreased patterns toward the pith in three of four analyzed trees (site-2 cedar, site- 5 cypress, and site-2 larch) (Fig. 4c-i). On the other hand, the ${ }^{137} \mathrm{Cs} /{ }^{133} \mathrm{Cs}$ ratio was similar between the sapwood and the outer heartwood and was almost constant throughout the heartwood in the other tree (site-1 cedar) sampled at $1 \mathrm{~m}$ above the ground (Fig. 4b). Remarkably, in the disk from the site- 1 cedar collected at $10 \mathrm{~m}$ above the ground, the ${ }^{137} \mathrm{Cs} /{ }^{133} \mathrm{Cs}$ ratio was higher in the heartwood than in the sapwood and showed an increased pattern toward the pith within the heartwood (Fig. 4a).

\section{Discussion}

\section{Vertical distribution of ${ }^{137} \mathrm{Cs}$ in the sapwood and heartwood}

As previously reported for Japanese cedars and red pines (Pinus densiflora) [4, 14, 18, 19], the vertical distribution of ${ }^{137}$ Cs activity concentration in the sapwood was almost uniform in all three species examined in this study. Because ${ }^{133} \mathrm{Cs},{ }^{85} \mathrm{Rb}$, and ${ }^{39} \mathrm{~K}$ showed similar distributions, alkali metals are considered to be highly mobile and/or evenly bound within the sapwood of these species. However, we should note that such uniform vertical distributions in the sapwood may not be common in all species, because Japanese oak (Quercus serrata) had higher ${ }^{137} \mathrm{Cs}$ activity concentrations in the upper parts of the stems [14].

A trend toward a higher ${ }^{137} \mathrm{Cs}$ activity concentration in the heartwood of the upper stem was commonly reported for Japanese cedars after the FDNPP accident $[4,18,19]$; however, its mechanism is not fully understood. The results of this study suggest four possible factors causing this trend. The first possible factor is the dilution effect of heartwood volume (heartwood cross-sectional area) suggested by statistical analysis of the HW/SW CR of ${ }^{137} \mathrm{Cs}$ (SW-to-HW model). In case accident-derived 


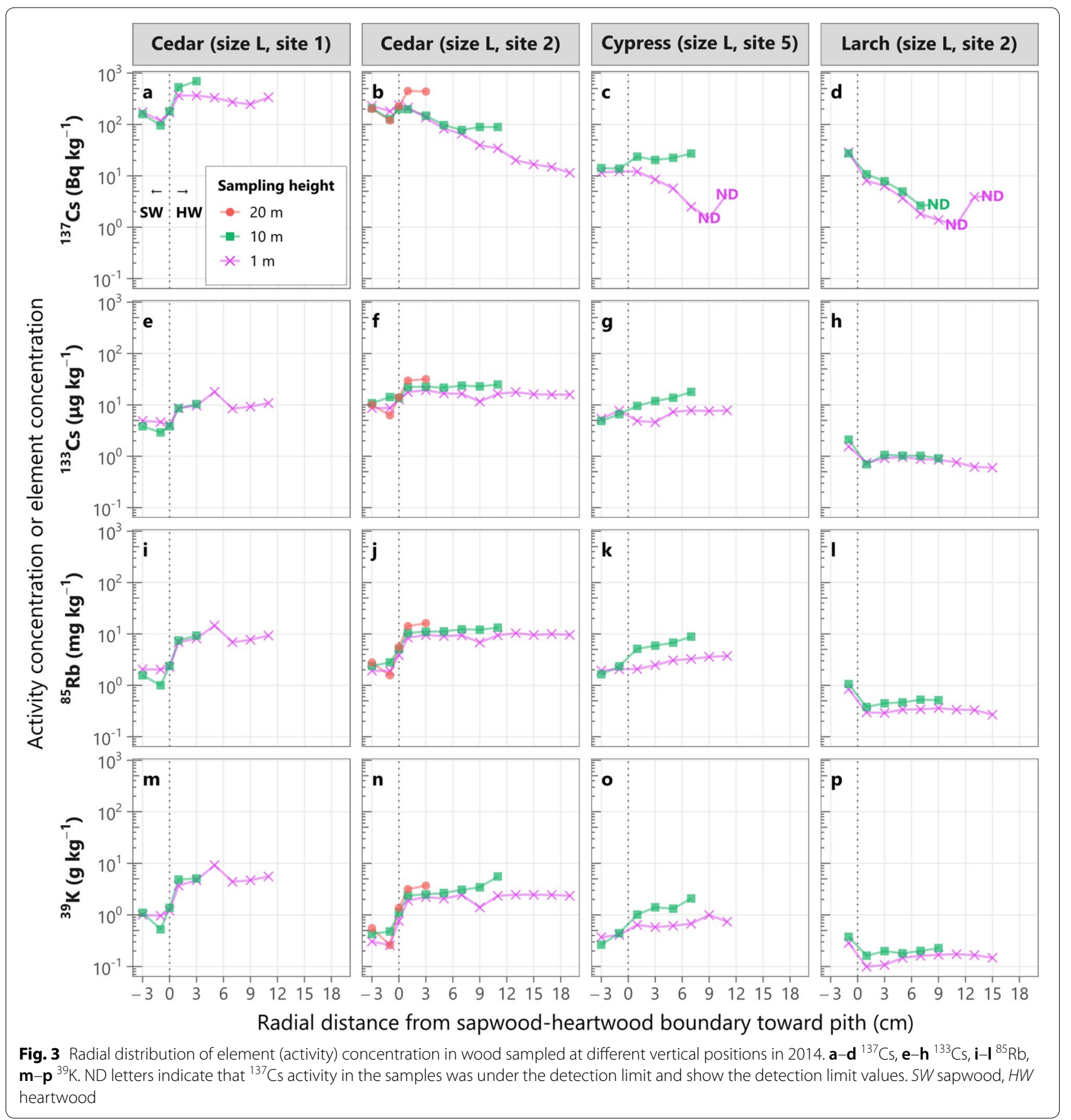

${ }^{137} \mathrm{Cs}$ transfers into the already-formed heartwood, the larger heartwood volume at the lower parts of the stem results in a relatively low ${ }^{137} \mathrm{Cs}$ activity concentration in the heartwood within a tree. The second possible factor is the initial foliar uptake of ${ }^{137} \mathrm{Cs}$ after the accident. As discussed in more detail later (see "Comparison between the distribution of ${ }^{137} \mathrm{Cs}$ and ${ }^{133} \mathrm{Cs}$ "), the fact that a higher ${ }^{137} \mathrm{Cs} /{ }^{133} \mathrm{Cs}$ ratio was found in the heartwood than in the sapwood of the upper stem (Fig. 4) suggests that the initial foliar uptake possibly increased the ${ }^{137} \mathrm{Cs}$ activity concentration in the heartwood of the upper stem. The third possible factor is slow downward diffusion of ${ }^{137} \mathrm{Cs}$ in the heartwood. Ogawa et al. [18] reported the possibility that downward diffusion homogenized the vertical distribution of ${ }^{137} \mathrm{Cs}$ activity concentration in the heartwood from 2011 to 2013. Because we still observed high 


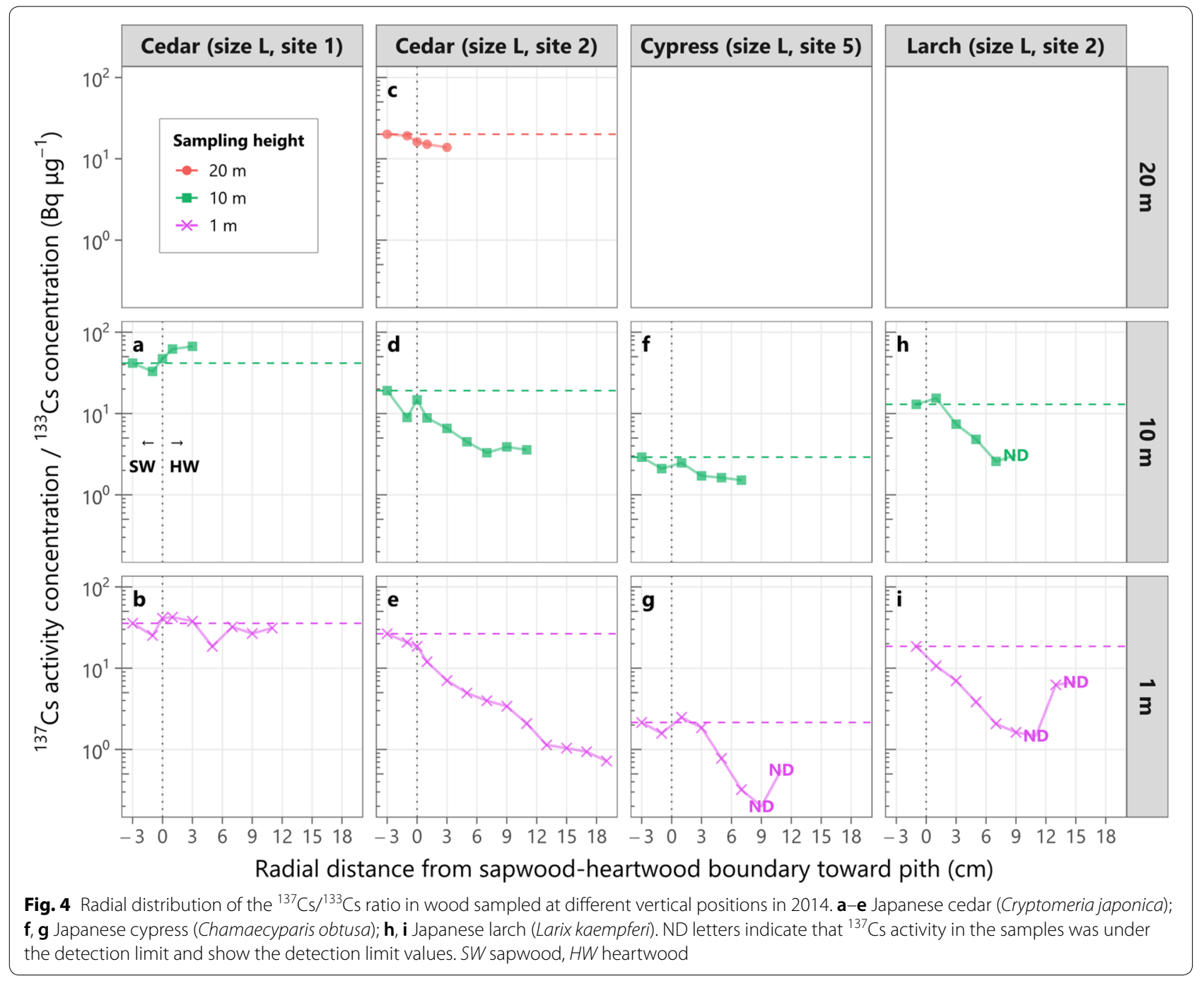

heterogeneity in 2014, the downward diffusion of ${ }^{137} \mathrm{Cs}$ in the heartwood is likely to be slow. The fourth possible factor is the intrinsic tendency of the vertical distribution of alkali metals. Although the tendency is not as pronounced as that of ${ }^{137} \mathrm{Cs}$, the concentrations of naturally distributed alkali metals also tended to be high in the upper stems (Fig. 3). This fact implies that the activity of the radial transport toward the heartwood might be higher at the upper stem; however, further studies are needed to understand such a physiological nature. We infer that these multiple factors cause the characteristic vertical distribution of ${ }^{137} \mathrm{Cs}$ in the heartwood in the nonequilibrium state.

\section{Transfer of ${ }^{137} \mathrm{Cs}$ from sapwood to heartwood}

It is known that the radial distributions of alkali metals in stem wood are species-dependent [23] and that an active transport by ray parenchyma cells can be involved in the radial transfer $[11,12,30]$. Statistical analysis using the SW-to-HW model demonstrated that the differences in the $\mathrm{HW} / \mathrm{SW} \mathrm{CR}$ of ${ }^{137} \mathrm{Cs}$ among the vertical positions of the stem within a tree, among trees of the same species, and between the cedar and site- 5 cypress were explained efficiently by the HWA of the disk, suggesting that the HW/SW CR of ${ }^{137} \mathrm{Cs}$ was dependent on the dilution effect of heartwood volume as of 2014. At the same time, the statistical analysis detected a difference that was not explained sufficiently by the HWA, and the HW/SW $\mathrm{CR}$ of ${ }^{137} \mathrm{Cs}$ was lower in the larch than in the other species. A similar difference was seen in the HW/SW CRs of stable alkali metals; the CRs were ca. 0.5 and did not differ among the elements in the larch, whereas the CRs were more than 1.0 and differed among the elements (high in order of $\mathrm{K}, \mathrm{Rb}$, and $\mathrm{Cs}$ ) in the other species. Such differences between the stable alkali metals imply that there is an active transport toward the heartwood 
targeting mainly $\mathrm{K}$ in the cedar and cypress and no active transport or rather an active transport toward the outer sapwood in the larch. Consequently, we infer that the difference between the larch and the other species in the SW-to-HW model arises from the different activity levels of radial transport toward the heartwood by ray parenchyma cells.

\section{Radial distribution of ${ }^{137} \mathrm{Cs}$ within the heartwood}

In contrast to the SW-to-HW model, the within-HW model selected in this study explained the differences in the $\mathrm{HW}_{\text {inner }} / \mathrm{HW}_{\text {outer }} \mathrm{CR}$ of ${ }^{137} \mathrm{Cs}$ among the species by the HWMC, without adding a species effect. This is quite a convincing result, because ${ }^{137} \mathrm{Cs}$ transfer within the heartwood must be caused only by diffusion [12], and the diffusibility obviously depends on the moisture content. Iizuka et al. [20] demonstrated that Japanese cedars with high HWMC (around 200\%) had higher ${ }^{137}$ Cs activity concentrations in the heartwood near the pith than did those with low HWMC (around 80\%). Although the HWMC of the cedar samples in this study was relatively low (below 100\%), it was found to be a useful variable to explain differences not only within the cedars, but also among the species. In addition, the HWMC value used in this study is the representative value for each individual and not the value for each disk. Because the HWMC can vary among vertical positions within a tree [31], using the HWMC value of each disk may improve the explanatory power of the model. The interpretation of the other fixed effect, D-from-T, which explains the differences in the $\mathrm{HW}_{\text {inner }} / \mathrm{HW}_{\text {outer }} \mathrm{CR}$ of ${ }^{137} \mathrm{Cs}$ among trees and among vertical positions within trees, remains unclear. Because D-from-T partly includes the effects of HWA, HWCLper-HWA, and CROWN, the selection of D-from-T in preference to the other effects suggests that the differences in the $\mathrm{HW}_{\text {inner }} / \mathrm{HW}_{\text {outer }} \mathrm{CR}$ of ${ }^{137} \mathrm{Cs}$ were likely to be due to multiple factors rather than a single factor.

\section{Comparison between the distributions of ${ }^{137} \mathrm{Cs}$ and ${ }^{133} \mathrm{Cs}$}

The radial distribution of the ${ }^{137} \mathrm{Cs} /{ }^{133} \mathrm{Cs}$ ratio in stem wood was investigated to clarify how different the distribution of accident-derived ${ }^{137} \mathrm{Cs}$ was from that of the naturally existing ${ }^{133} \mathrm{Cs}$ as of 2014 . Assuming that ${ }^{137} \mathrm{Cs}$ and ${ }^{133} \mathrm{Cs}$ in the outermost sapwood are well mixed and their ratio represents the latest value at the time of the sampling, we categorized the radial distribution patterns of the ${ }^{137} \mathrm{Cs} /{ }^{133} \mathrm{Cs}$ ratio into three types to discuss the characteristics of ${ }^{137} \mathrm{Cs}$ distribution. In type 1 , the ${ }^{137} \mathrm{Cs} /{ }^{133} \mathrm{Cs}$ ratios in the heartwood are lower than those in the sapwood and decrease toward the pith; in type 2, the ratios are similar from the outer sapwood to the inner heartwood; in type 3 , the ratios in the heartwood are higher than those in the sapwood and increase toward the pith (i.e., the reverse pattern to type 1 ).

The type 1 radial distribution pattern indicates that not as much ${ }^{137} \mathrm{Cs}$ had transferred to the inner parts of the heartwood compared with the ${ }^{133} \mathrm{Cs}$ distribution pattern. Thus, it seems to take a longer time or be more difficult for ${ }^{137} \mathrm{Cs}$ to achieve the same distribution pattern as ${ }^{133} \mathrm{Cs}$ in stem wood of this type. Three out of four trees analyzed in this study were categorized as type 1 . Although data on the radial distribution of both ${ }^{137} \mathrm{Cs}$ and ${ }^{133} \mathrm{Cs}$ are scarce, from analysis of the data reported by Mahara et al. [17], the ${ }^{137} \mathrm{Cs} /{ }^{133} \mathrm{Cs}$ ratio patterns in a Japanese cedar and oak (Quercus serrata) collected in 2012 were found to be type 1 . Therefore, several years after the accident, type 1 was probably the common pattern in mature trees with a substantial amount of heartwood, suggesting that ${ }^{137} \mathrm{Cs}$ distribution was still in the non-equilibrium state.

The type 2 pattern suggests that ${ }^{137} \mathrm{Cs}$ had already transferred to the inner parts of the heartwood as much as the ${ }^{133} \mathrm{Cs}$ distribution pattern. Because the ${ }^{137} \mathrm{Cs} /{ }^{133} \mathrm{Cs}$ ratio pattern in a Scots pine collected 12 years after the CNPP accident was type $2[21],{ }^{137} \mathrm{Cs}$ distribution in the stem wood of type 2 is considered to be in an equilibrium state, and its pattern is expected to be unchanged in the future. This type was found in the site- 1 cedar, which had relatively high HWMC (97\%; Fig. 4b) compared with the other trees (HWMC 35-53\%). Thus, as suggested by the within-HW model, high HWMC is likely to be one of the factors causing type 2 .

Type 3, which was found in the disk of the site- 1 cedar collected at $10 \mathrm{~m}$ above the ground (Fig. 4a), is a remarkable pattern, indicating that the ${ }^{137} \mathrm{Cs}$ activity concentration in the sapwood was considerably higher in the past than at the time of sampling (in other words, ${ }^{137} \mathrm{Cs}$ concentration decreased at a greater rate than radioactive decay of ${ }^{137} \mathrm{Cs}$ ). This pattern could have happened when the initial foliar uptake of ${ }^{137} \mathrm{Cs}$ shortly after the accident was dominant and the subsequent root uptake was not dominant. In addition, the relatively high concentration of ${ }^{137} \mathrm{Cs}$ obtained by the initial foliar uptake must have transferred to the inner heartwood sufficiently to form the pattern of type 3 . Although it is difficult to estimate the initial foliar uptake, the subsequent root uptake is inferred to be not dominant in the site- 1 cedars from the observation that the ${ }^{137} \mathrm{Cs}$ activity concentration in the sapwood of the site- 1 cedars did not change significantly from 2011 to 2016 [24]. From this point of view, the site- 2 cedar, in which root uptake of ${ }^{137} \mathrm{Cs}$ is inferred to be dominant [24], and the larch, which did not have foliar uptake because of the absence of foliage at the time of the deposition event, are expected to have no type 3 pattern; and actually the site- 2 cedar and the larch were not categorized as type 3 but as type 1 . This study showed 
that the type 3 pattern persisted for at least 3 years after the accident, although it may become indistinct as the fraction of newly formed heartwood increases. Consequently, the distribution of ${ }^{137} \mathrm{Cs}$ in stem wood was suggested to be affected not only by the tree's internal factors (e.g., HWMC and active transport), but also by environmental factors (foliar and root uptake) and the course of time.

\section{Conclusions}

In mature trees that had a substantial amount of heartwood at the time of the FDNPP accident in 2011, the vertical distribution of ${ }^{137} \mathrm{Cs}$ activity concentration in the sapwood was relatively uniform for all species, while the vertical and radial distributions in the heartwood were heterogeneous as of 2014, and the radial distribution pattern varied among species, individuals, and vertical positions within individuals. Statistical analysis suggested that the differences in radial distribution patterns within the heartwood among species can be explained by heartwood moisture content. On the other hand, there was an unexplained difference between the larch and the other two species in the radial distribution patterns between sapwood and heartwood. Taking the distribution patterns of stable alkali metals $\left({ }^{133} \mathrm{Cs},{ }^{85} \mathrm{Rb}\right.$, and $\left.{ }^{39} \mathrm{~K}\right)$ into account, such species dependency in the radial distributions between sapwood and heartwood was inferred to be due to the different activity levels of the radial transport of alkali metals toward the heartwood by ray parenchyma cells.

The radial distribution pattern of the ${ }^{137} \mathrm{Cs} /{ }^{133} \mathrm{Cs}$ ratio showed that not as much ${ }^{137} \mathrm{Cs}$ had transferred to the inner parts of the heartwood compared with the ${ }^{133} \mathrm{Cs}$ distribution pattern in the majority of analyzed trees as of 2014. However, there was also a tree in which ${ }^{137} \mathrm{Cs}$ was transferred to the inner heartwood excessively compared with the ${ }^{133} \mathrm{Cs}$ distribution pattern. We deduced that such patterns could be found in a tree that had significant foliar uptake of ${ }^{137} \mathrm{Cs}$ initially and poor root uptake subsequently after the accident, in addition to having high heartwood moisture content. Although analysis of the ${ }^{137} \mathrm{Cs} /{ }^{133} \mathrm{Cs}$ ratio is useful to understand the current situation of ${ }^{137} \mathrm{Cs}$ distribution and to predict possible temporal changes in the future, follow-up monitoring and studies will be necessary to determine how rapidly transfer of ${ }^{137} \mathrm{Cs}$ to the heartwood progresses and when it reaches an equilibrium state.

\footnotetext{
Abbreviations

FDNPP: Fukushima Dai-ichi Nuclear Power Plant; CNPP: Chernobyl Nuclear Power Plant; DBH: Diameter at breast height; CR: Concentration ratio; SW: Sapwood; HW: Heartwood; HWA: Heartwood cross-sectional area; HWCL:
}

Heartwood circumferential length; HWMC: Heartwood moisture content; VIF: Variance inflation factor; AIC: Akaike's information criterion.

\section{Acknowledgements}

We would like to thank Dr. K. Yamamoto for his great assistance with sampling and sample preparations. We also thank the Center for Forest Restoration and Radioecology of FFPRI for performing the ${ }^{137} \mathrm{Cs}$ measurements, and Drs. C. Zhang and J. Nagakura for assisting us in measuring the concentrations of elements.

\section{Authors' contributions}

SO analyzed the data and wrote the draft of this manuscript. All authors contributed to designing the experiment, collecting and preparing the samples for the analyses, and writing the final manuscript. All authors read and approved the final manuscript.

\section{Funding}

This study was funded by research Grant \#201501 from the Forestry and Forest Products Research Institute.

\section{Availability of data and materials}

The datasets used and/or analyzed during the current study are available from the corresponding author on reasonable request.

\section{Competing interests}

The authors declare that they have no competing interests.

\section{Author details}

${ }^{1}$ Department of Wood Properties and Processing, Forestry and Forest Products Research Institute, 1 Matsunosato, Tsukuba, Ibaraki 305-8687, Japan. ${ }^{2}$ Center for Forest Restoration and Radioecology, Forestry and Forest Products Research Institute, 1 Matsunosato, Tsukuba, Ibaraki 305-8687, Japan. ${ }^{3}$ Forest Bio-Research Center, Forestry and Forest Products Research Institute, 3809-1 Ishi, Juo, Hitachi, Ibaraki 319-1301, Japan.

Received: 2 April 2020 Accepted: 5 June 2020

Published online: 12 June 2020

\section{References}

1. Calmon P, Thiry Y, Zibold G, Rantavaara A, Fesenko S (2009) Transfer parameter values in temperate forest ecosystems: a review. J Environ Radioact 100:757-766. https://doi.org/10.1016/j.jenvrad.2008.11.005

2. Tagami K, Uchida S, Ishii N, Kagiya S (2012) Translocation of radiocesium from stems and leaves of plants and the effect on radiocesium concentrations in newly emerged plant tissues. J Environ Radioact 111:65-69. https://doi.org/10.1016/j.jenvrad.2011.09.017

3. Nishikiori T, Watanabe M, Koshikawa MK, Takamatsu T, Ishii Y, Ito S, Takenaka A, Watanabe K, Hayashi S (2015) Uptake and translocation of radiocesium in cedar leaves following the Fukushima nuclear accident. Sci Total Environ 502:611-616. https://doi.org/10.1016/j.scito tenv.2014.09.063

4. Masumori M, Nogawa N, Sugiura S, Tange T (2015) Radiocesium in stem, branch and leaf of Cryptomeria japonica and Pinus densiflora trees: cases of forests in Minamisoma in 2012 and 2013. J Jpn For Soc 97:51-56 (in Japanese with English abstract)

5. Kato H, Onda Y, Hisadome K, Loffredo N, Kawamori A (2017) Temporal changes in radiocesium deposition in various forest stands following the Fukushima Dai-ichi Nuclear Power Plant accident. J Environ Radioact 166:449-457. https://doi.org/10.1016/j.jenvrad.2015.04.016

6. Wang W, Hanai Y, Takenaka C, Tomioka R, lizuka K, Ozawa H (2016) Cesium absorption through bark of Japanese cedar (Cryptomeria japonica). J For Res 21:251-258. https://doi.org/10.1007/s10310-016-0534-5

7. Wang W, Takenaka C, Tomioka R, Kanasashi T (2018) Absorption and translocation of cesium through Konara oak (Quercus serrata) bark. J For Res 23:21-27. https://doi.org/10.1080/13416979.2018.1426898

8. Ohta T, Torimoto J, Kubota T, Mahara Y (2016) Front tracking of the translocation of water-soluble cesium deposited on tree leaves of plum. J Radioanal Nucl Chem 310:109-115. https://doi.org/10.1007/s1096 7-016-4791-8 
9. van Bel AJE (1990) Xylem-phloem exchange via the rays: the undervalued route of transport. J Exp Bot 41:631-644

10. Aoki D, Asai R, Tomioka R, Matsushita Y, Asakura H, Tabuchi M, Fukushima K (2017) Translocation of ${ }^{133} \mathrm{Cs}$ administered to Cryptomeria japonica wood. Sci Total Environ 584-585:88-95. https://doi.org/10.1016/j.scito tenv.2017.01.159

11. Kuroda K, Yamane K, Itoh Y (2018) Cellular level in planta analysis of radial movement of artificially injected caesium in Cryptomeria japonica xylem. Trees 32:1505-1517. https://doi.org/10.1007/s00468-018-1729-5

12. Kuroda K, Yamane K, Itoh Y (2020) Radial movement of minerals in the trunks of standing Japanese cedar (Cryptomeria japonica D. Don) trees in summer by tracer analysis. Forests 11:562. https://doi.org/10.3390/f1105 0562

13. Kuroda K, Kagawa A, Tonosaki M (2013) Radiocesium concentrations in the bark, sapwood and heartwood of three tree species collected at Fukushima forests half a year after the Fukushima Dai-ichi nuclear accident. J Environ Radioact 122:37-42. https://doi.org/10.1016/j.jenvr ad.2013.02.019

14. Ohashi S, Okada N, Tanaka A, Nakai W, Takano S (2014) Radial and vertical distributions of radiocesium in tree stems of Pinus densiffora and Quercus serrata $1.5 \mathrm{y}$ after the Fukushima nuclear disaster. J Environ Radioact 134:54-60. https://doi.org/10.1016/j.jenvrad.2014.03.001

15. Nakada R, Fujisawa Y, Hirakawa Y (1999) Soft X-ray observation of water distribution in the stem of Cryptomeria japonica D. Don I: general description of water distribution. J Wood Sci 45:188-193

16. Nakada R, Fujisawa Y, Hirakawa Y (1999) Soft X-ray observation of water distribution in the stem of Cryptomeria japonica D. Don II: types found in wet-area distribution patterns in transverse sections of the stem. J Wood Sci 45:194-199

17. Mahara Y, Ohta T, Ogawa H, Kumata A (2014) Atmospheric direct uptake and long-term fate of radiocesium in trees after the Fukushima nuclear accident. Sci Rep 4:7121. https://doi.org/10.1038/srep07121

18. Ogawa H, Hirano Y, Igei S, Yokota K, Arai S, Ito H, Kumata A, Yoshida H (2016) Changes in the distribution of radiocesium in the wood of Japanese cedar trees from 2011 to 2013. J Environ Radioact 161:51-57. https ://doi.org/10.1016/j.jenvrad.2015.12.021

19. Yoschenko V, Takase T, Konoplev A, Nanba K, Onda Y, Kivva S, Zheleznyak M, Sato N, Keitoku K (2017) Radiocesium distribution and fluxes in the typical Cryptomeria japonica forest at the late stage after the accident at Fukushima Dai-Ichi Nuclear Power Plant. J Environ Radioact 166:45-55. https://doi.org/10.1016/j.jenvrad.2016.02.017

20. lizuka K, Toya N, Ohshima J, Ishiguri F, Miyamoto N, Aizawa M, Ohkubo T, Takenaka C, Yokota S (2018) Relationship between ${ }^{137}$ Cs concentration and potassium content in stem wood of Japanese cedar (Cryptomeria japonica). J Wood Sci 64:59-64. https://doi.org/10.1007/s1008 6-017-1673-9
21. Yoshida S, Watanabe M, Suzuki A (2011) Distribution of radiocesium and stable elements within a pine tree. Radiat Prot Dosim 146:326-329. https ://doi.org/10.1093/rpd/ncr181

22. Kohno M, Koizumi Y, Okumura K, Mito I (1988) Distribution of environmental Cesium-137 in tree rings. J Environ Radioact 8:15-19. https://doi. org/10.1016/0265-931X(88)90011-2

23. Okada N, Katayama Y, Nobuchi T, Ishimaru Y, Aoki A (1993) Trace elements in the stems of trees $V$. Comparisons of radial distributions among softwood stems. Mokuzai Gakkaishi 39:1111-1118

24. Ohashi S, Kuroda K, Takano T, Suzuki Y, Kubojima Y, Zhang C, Yamamoto $\mathrm{K}$ (2017) Temporal trends in ${ }^{137} \mathrm{Cs}$ concentrations in the bark, sapwood, heartwood, and whole wood of four tree species in Japanese forests from 2011 to 2016. J Environ Radioact 178-179:335-342. https://doi. org/10.1016/j.jenvrad.2017.09.008

25. Ministry of Education, Culture, Sports, Science and Technology, Japan (2013) Results of deposition of radioactive cesium of the sixth airborne monitoring survey and airborne monitoring survey outside $80 \mathrm{~km}$ from the Fukushima Dai-ichi NPP. http://emdb.jaea.go.jp/emdb/assets/ site_data/en/csv_utf8/765/765_00.csv.zip. Accessed 4 Feb 2016

26. Soukhova NV, Fesenko SV, Klein D, Spiridonov SI, Sanzharova NI, Badot PM (2003) ${ }^{137}$ Cs distribution among annual rings of different tree species contaminated after the Chernobyl accident. J Environ Radioact 65:19-28. https://doi.org/10.1016/S0265-931X(02)00061-9

27. R Core Team (2019) R: a language and environment for statistical computing. Vienna: R Foundation for Statistical Computing. https://www.r-proje ct.org/

28. Robinson C, Schumacker R (2009) Interaction effects: centering, variance inflation factor, and interpretation issues. Mult Linear Regres Viewpoints 35:6-11

29. Bates D, Maechler M, Bolker B, Walker S (2015) Fitting linear mixed-effects models using Ime4. J Stat Softw 67:1-48. https://doi.org/10.18637/jss. v067.01

30. Okada N, Hirakawa Y, Katayama Y (2011) Application of activable tracers to investigate radial movement of minerals in the stem of Japanese cedar (Cryptomeria japonica). J Wood Sci 57:421-428. https://doi.org/10.1007/ s10086-011-1188-8

31. Nakada R, Fujisawa Y, Yamashita K, Hirakawa Y (2003) Changes in water distribution in heartwood along stem axes in Cryptomeria japonica. J Wood Sci 49:107-115. https://doi.org/10.1007/s100860300017

\section{Publisher's Note}

Springer Nature remains neutral with regard to jurisdictional claims in published maps and institutional affiliations.

\section{Submit your manuscript to a SpringerOpen ${ }^{\circ}$ journal and benefit from:}

- Convenient online submission

- Rigorous peer review

- Open access: articles freely available online

- High visibility within the field

- Retaining the copyright to your article

Submit your next manuscript at $\boldsymbol{\nabla}$ springeropen.com 